\title{
CONTROL OF CELL pH IN IMMATURE PRIMITIVE RED CELLS FROM CHICK EMBRYO
}

\author{
Ulrich Steger, Christoph Reinhardt and Rosemarie BaumanN* \\ Physiologisches Institut, Universität Regensburg, Postfach 397, 84 Regensburg, Germany
}

(Tel. 0941-943-2956; Fax 0941-943-4315)

(Received 25 June 1992; accepted 31 July 1992)

\begin{abstract}
The intracellular $\mathrm{pH}$ in primitive red cells from 4 day chick embryos was measured with the digitonin null-point method and the fluorescent indicator SNARF-1. At physiological $\mathrm{pH}_{e}$ of 8.0 red cell $\mathrm{pH}$ is 7.39 at day 4 .

2. The calculated proton equilibrium potential of $-38 \mathrm{mV}$ is in good agreement with previous measurements of $\mathrm{E}_{\mathrm{m}}$ (Engelke $e t$ al., 1988) and supports the conclusion that the $\mathrm{E}_{\mathrm{m}}$ is dominated by a proton conductance.

3. The sodium-proton exchanger is present in primitive red cells but quiescent under physiological conditions.

4. The results indicate that the bicarbonate-chloride exchange via Band 3 protein is impaired.
\end{abstract}

\section{INTRODUCTION}

Primitive erythrocytes which originate in the yolk sac of higher vertebrates constitute the first red cell population of the embryo. In the chick embryo a closed circulatory system is established by the end of the second day of incubation. The primitive red cells enter the vascular system as a cohort of immature erythroblasts which carry out their terminal differentiation (including several mitoses) inside the vascular system. While the oxygen binding properties of the primitive red cells have been assessed from day 3 onwards (Baumann et al., 1982; Lapennas and Reeves, 1983) the mechanisms that control red cell $\mathrm{pH}-\mathrm{a}$ major determinant of hemoglobin oxygen affinity-during early development have not yet been studied in greater detail.

In adult red cells of birds and mammals the distribution of chloride, bicarbonate and protons follows the Donnan equilibrium (Hladky and Rink, 1977; Kregenow, 1977), and rapid equilibrium between chloride and bicarbonate is achieved through the presence of the Band 3 anion transporter. During embryonic development Band 3 first appears in the red cell membranes of 3-day-old chick embryos (Chan, 1977).

Direct measurements of red cell pH (in the absence of carbon dioxide) have been obtained only for mature primitive red cells from 6 day chick embryos. They demonstrated a large $\mathrm{pH}$ difference of about 0.6 units (Baumann et al., 1982, Baumann and Haller, 1983).

Measurements of the membrane potential of primitive red cells have demonstrated the presence of a proton conductance and the measured potential is

*To whom all correspondence should be addressed. considerably more negative than the chloride equilibrium potential (Engelke et al., 1988). These data suggest that Band 3 function is altered in primitive red cells. In the present investigation we have measured directly the $\mathrm{pH}$ of red cells from early chick embryos in the absence and presence of carbon dioxide and assessed the presence of the sodiumproton antiport.

The results show that the sodium-proton exchanger is present in these cells but is quiescent under physiological conditions. Furthermore we have obtained additional experimental evidence to support the hypothesis that in immature primitive erythrocytes the hetero-exchange of bicarbonate and chloride across the Band 3 protein is impaired, causing a disequilibrium of bicarbonate and chloride distribution across the red cell membrane.

\section{MATERIALS AND METHODS}

Fertilized eggs were incubated for 4 days at $37.5^{\circ} \mathrm{C}$ and $60 \%$ r.h. in an incubator with automatic rotation. At day 4 the eggs were opened and red cells aspirated from extracellular blood vessels and transferred into cold buffer $(\mathrm{pH} 7.4,20 \mathrm{mmol} / \mathrm{l}$ Tris, $146 \mathrm{mmol} / 1 \mathrm{NaCl}, 4 \mathrm{mmol} / 1 \mathrm{KCl}, 1.5 \mathrm{mmol} / 1 \mathrm{CaCl}_{2}$ and $5 \mathrm{mmol} / \mathrm{l}$ glucose). The cells were washed twice in the buffer and then prepared for the cell $\mathrm{pH}$ measurements.

\section{Measurement of cell $p H$}

The cell $\mathrm{pH}$ of the red cells was determined by two methods:

The digitonin null-point method ( $R$ ink et al., 1982). This method has been shown to give reliable estimates of mean cytoplasmic pH (Rink et al., 1982). The main disadvantage of the method is that it needs 

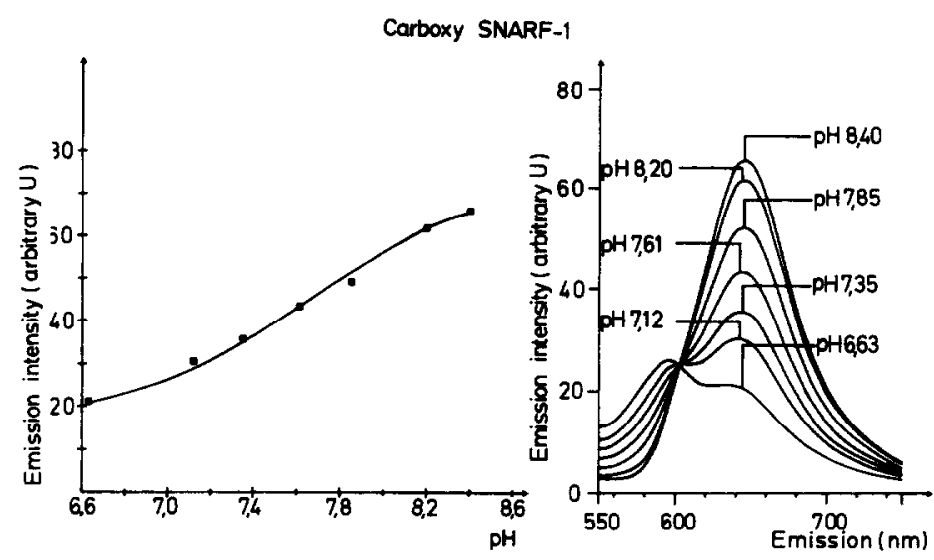

Excitation $=540 \mathrm{~nm}$

Fig. 1. Left panel: pH dependent emission of SNARF-1 at $640 \mathrm{~nm}$, excitation at $540 \mathrm{~nm}$ and $37^{\circ} \mathrm{C}$. Right panel: pH dependent emission spectrum of SNARF-1 after digitonin lysis of red cell sample.

fairly large amounts of material and cannot be used to determine cell $\mathrm{pH}$ in the presence of $\mathrm{CO}_{2}$, since measurements are made in unbuffered solutions. For the cell $\mathrm{pH}$ determinations the cells were first incubated for $30 \mathrm{~min}$ in the respective buffer solution $\left(140 \mathrm{mmol} / 1 \mathrm{NaCl}, 5 \mathrm{mmol} / 1 \mathrm{KCl}, 2 \mathrm{mmol} / 1 \mathrm{CaCl}_{2}\right.$, $1 \mathrm{mmol} / \mathrm{MgCl}_{2}, 5 \mathrm{mmol} / \mathrm{glucose}, 20 \mathrm{mmol} / \mathrm{l}$ Tris or Hepes). The $\mathrm{pH}$ of the incubation buffer varied from $\mathrm{pH}$ 7.0 to 8.5. At the end of the incubation period the solution was rapidly centrifuged and $5 \mu 1$ of the packed red cells transferred to $1.5 \mathrm{ml}$ unbuffered solution with the same composition as above except for Tris/Hepes. The $\mathrm{pH}$ of this solution was adjusted to the value of the respective incubation buffer by addition of $\mathrm{NaOH}$ or $\mathrm{HCl}$.

Immediately after resuspension the cells were permeabilized by addition of $20 \mu 1$ of a $20 \mathrm{mmol}$ digitonin stock solution. The change of the extracellular $\mathrm{pH}\left(\mathrm{pH}_{\mathrm{e}}\right)$ was registered on an $\mathrm{x}-\mathrm{t}$ recorder.

The cell $\mathrm{pH}$ is taken to correspond to the external $\mathrm{pH}$ where no change in $\mathrm{pH}_{\mathrm{e}}$ is recorded after addition of digitonin.

Measurement of the cell $p H$ with the fluorescent indicator SNARF/AM-1 (Molecular Probes Inc.). The commonly used indicator BCECF was found unsuitable for cell $\mathrm{pH}$ measurements due to large quenching artifacts and rapid leakage of BCECF from the embryonic erythrocytes.

We have now established a protocol for use of the recently introduced fluorescent dye CarboxySNARF-1 (Molecular Probes. Inc) which allows reliable measurements in the physiological $\mathrm{pH}$ range. Figure 1 shows the emission spectrum of SNARF/-1 as a function of $\mathrm{pH}$. The excitation wavelength was $540 \mathrm{~nm}$.

For our measurements the fluorescence signal was taken in the ratio mode $\left(\right.$ Emission $_{600} /$ Emission $\left._{603}\right)$ with excitation at $540 \mathrm{~nm}$. All measurements were carried out on a Shimazdu RF-540 fluorescencespectrophotometer.

\section{Calibration}

The presence of an independent electrogenic proton conductivity in the membrane of the embryonic red cell (Engelke et al., 1988) does not allow the usual calibration of the fluorescence signal with nigericin (Thomas, 1986), which requires that protons follow the distribution of the potassium ions. This condition is only met if other pathways for proton transport are negligible, since otherwise their presence acts as a proton shunt. In keeping with this we observed only minimal changes of the fluorescence signal in the presence of nigericin.

We therefore used the following calibration procedure which initially relied on the cell $\mathrm{pH}$ values obtained with the digitonin-null point method.

Red cells were incubated with SNARF/AM-1 (final concentration $1.5 \mu \mathrm{mol}$ ) at $\mathrm{pH} 8.0$ for $30 \mathrm{~min}$ at $37^{\circ} \mathrm{C}$. Under these conditions the intracellular $\mathrm{pH}$ as determined by the digitonin-nullpoint method is 7.4 (Fig. 2).

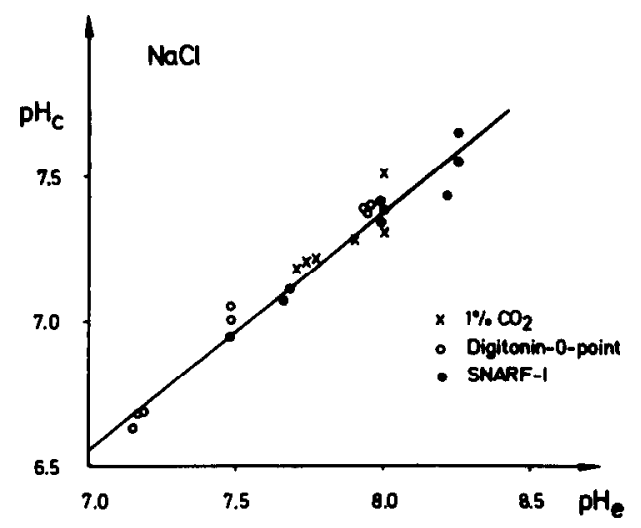

Fig. 2. Dependence of cell $\mathrm{pH}$ on external $\mathrm{pH}$ as measured with the digitonin-null point method (open circles) or SNARF-1 (filled circles). Cell $\mathrm{pH}$ measurements in the presence of carbon dioxide were obtained with SNARF-1. All measurements were performed at $37^{\circ} \mathrm{C}$. 
At the end of the incubation period cells were washed twice for $20 \mathrm{sec}$ with incubation buffer of increased density ( $50 \mathrm{~g}$ Ficoll $400 / 1$ added). The increased density facilitates removal of extracellular dye compared to the results obtained when washing with normal buffer.

The pellet ( $2 \mu 1$ packed cells) was transferred into the cuvette containing $2 \mathrm{ml}$ buffer (pH 8.0). The emission ratio was recorded, the suspension rapidly centrifuged and the cell pellet quickly transferred into buffer of $\mathrm{pH} 7.4$ (so that initially $\mathrm{pH}_{\mathrm{e}}=\mathrm{pH}_{\mathrm{i}}$ ). The ratio was immediately recorded before and after addition of digitonin.

Under the assumption that $\mathrm{pH}_{\mathrm{i}}=\mathrm{pH}_{\mathrm{c}}$ and provided that little or no intracellular quenching occurs, the fluorescence signal obtained before and after addition of digitonin should be identical.

We found in a typical set of experiments that there was only a small, undirected change of the ratio after addition of digitonin, amounting at most to an error of cell $\mathrm{pH}$ determination of about 0.05 to $0.1 \mathrm{pH}$ units. Since these results suggest no specific quenching artifacts, one can use the simple digitonin lysis method for standardization of the fluorescence measurements; i.e. cells were lysed with digitonin after the measurement and the emission ratio recorded for stepwise changes of $\mathrm{pH}$ using $0.5 \mathrm{M}$ HCL as a titrant. The main set-back of the method is that although dye leakage is much smaller than for BCECF is obtained only for the first few min. Therefore the dye cannot be used to monitor cell-pH continuously in embryonic red cells.

All readings were performed within $3 \mathrm{~min}$ after transfer of the cells to the fluorescence spectrophotometer.

For measurements of cell pH in the presence of $\mathrm{CO}_{2}$ the following procedure was adopted. Cells were incubated with dye for $30 \mathrm{~min}$ in bicarbonate buffer (composition as above except that Tris was replaced by a mixture of Hepes and bicarbonate to yield the desired $\mathrm{pH}$ ) in a gas mixture of $1 \% \mathrm{CO}_{2}$ in air. The gas mixture was saturated with water vapor and was provided by a Wösthoff gas mixing pump Type SA $27 \mathrm{~F}$.

After incubation the sample was transferred anaerobically with a blood-gas syringe into Eppendorf tubes $(2.2 \mathrm{ml})$ filled with $200 \mu \mathrm{l}$ incubation buffer which had been equilibrated with the same gas mixture. The sample was layered under the buffer and centrifuged for $20 \mathrm{sec}$. The cell pellet was then washed rapidly twice with $\mathrm{CO}_{2}$ equilibrated incubation buffer of higher density and after the final wash the pellet was resuspended in $40 \mu 1$ fresh medium and immediately transferred with a gas-tight Hamilton syringe into anaerobic cuvettes (Fa. Hellma) sealed with teflon caps. The cuvettes contained $1960 \mu 1$ incubation buffer equilibrated with the $\mathrm{CO}_{2}$ /air gas mixture. The $\mathrm{pH}$ of the buffer was measured anaerobically using the AVL Gas Check 939 blood gas analyser. All other procedures were as described above.
To test the dependence of cell $\mathrm{pH}$ on the presence of external sodium or chloride the ions were substituted by choline and gluconate respectively.

Red cell concentrations of sodium and potassium were determined by flame photometry, chloride by coulometric titration (Aminco Cotlove) as described previously (Engelke et al., 1988). All concentrations are given as $\mathrm{mmol} / \mathrm{kg}$ cell water. The wet and dry weights were determined as described elsewhere (Engelke et al., 1988).

SNARF/AM-1 was obtained from Molecular Probes and a stock solution of $1 \mathrm{mmol} / \mathrm{l}$ dissolved in DMSO was prepared. Amiloride was a kind gift of Merck, Darmstadt, Germany. All other reagents were obtained from Sigma chemicals St Louis, MO. A stock solution of DIDS (4,4'diisothiocyano-2,2'disulfonic acid stilbene) was prepared daily at $1 \times 10^{-2} \mathrm{M}$ in aqueous solution.

\section{RESULTS}

\section{Red cell $\mathrm{pH}$ in norminally $\mathrm{CO}_{2}$ free solutions}

Figure 2 shows the combined results of the cell $\mathrm{pH}$ measurements obtained with either the digitonin-null point method or the fluorescent indicator SNARF/1 under standard conditions. Both sets of data are in good agreement. With an estimated pK of around 7.5 SNARF/ 1 is a sensitive indicator in the physiological $\mathrm{pH}$ range.

Previous measurements of extracellular $\mathrm{pH}$ in various parts of the embryonic circulation at day 4 (Meuer et al., 1989) have shown that the $\mathrm{pH}$ in the vitelline vein, which carries the oxygenated blood to the embryonic heart is 8.0 , whereas the $\mathrm{pH}$ in the intraembryonic circulation drops to 7.64 (jugular vein). Thus the physiological extracellular $\mathrm{pH}$ range for erythrocytes of the 4 day embryo is 8.0-7.6 and the corresponding values for $\mathrm{pH}_{\mathrm{i}}$ are 7.39 and 7.09 as calculated from the common regression equation (equation 1).

$$
\mathrm{pH}_{\mathrm{i}}=0.73085+0.833 \mathrm{pH}_{c} ; \quad r=0.98469
$$

When the embryonic red cells were treated with DIDS (30 min incubation in the dark with a final concentration of $5 \times 10^{-4} \mathrm{~mol}$ ) in order to inhibit anion-transport via the Band 3 protein, cell $\mathrm{pH}$ did not change (at $\mathrm{pH}_{\mathrm{e}}=8.0 \mathrm{pH}_{\mathrm{i}}=7.37$, mean value from six experiments). On the other hand substitution of external chloride by gluconate (in the absence of DIDS) caused a moderate alkalinization (Fig. 3). After $30 \mathrm{~min}$ incubation in gluconate the intracellular $\mathrm{pH}$ increased by about $0.15 \mathrm{pH}$ units. $\mathrm{At}_{\mathrm{pH}} 8.0$ the $\mathrm{pH}_{\mathrm{i}}$ is 7.56 .

When external sodium was replaced by choline during the incubation period (Fig. 4) we observed no significant decrease of the intracellular $\mathrm{pH}$ compared to the controls. This indicates that sodium-proton exchange is quiescent under these conditions (i.e. in the physiological $\mathrm{pH}$ range). 


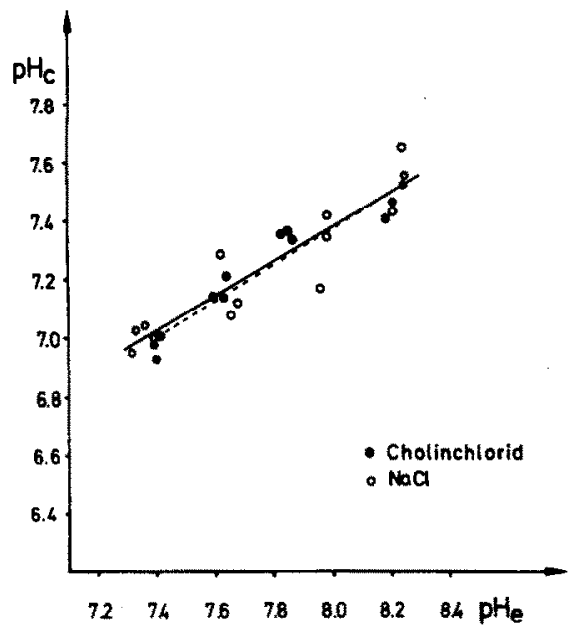

Fig. 3. Effect of substitution of external sodium by choline on cell $\mathrm{pH}$.

Note also that the possible gradient for the $\mathrm{Na}^{+}-\mathrm{H}^{+}$exchange is much smaller than for adult red cells, since the intracellular sodium concentration is 97 and $83 \mathrm{mmol} / \mathrm{kg} \mathrm{H}_{2} \mathrm{O}$ at $\mathrm{pH}_{\mathrm{e}} 7.0-8.0$ (mean values from 4 experiments).

Since these results gave no indication for the presence of a sodium proton exchange we conducted a second series of experiments. We incubated the red cells for $20 \mathrm{~min}$ in buffer with high extracellular sodium $(140 \mathrm{mmol} / \mathrm{l})$ at a low extracellular $\mathrm{pH}$ of 6.6 (cell $\mathrm{pH}$ is 6.15 as measured by digitonin-nullpoint). Under these conditions the intracellular sodium concentration is about $100 \mathrm{mmol} / \mathrm{kg} \mathrm{H}_{2} \mathrm{O}$. The cell suspension was rapidly centrifuged and the pellet $(20 \mu \mathrm{l})$ transferred into an unbuffered $(1.5 \mathrm{ml})$ solution of $140 \mathrm{mmol}$ choline chloride $\mathrm{pH}$ 6.6.

This causes a steep inward gradient for the uptake of protons. The initial rate of proton influx was recorded in the absence and presence of $0.5 \mathrm{mmol} / 1$ amiloride by following the change in $\mathrm{pH}_{e}$. We found that in the absence of amiloride initial proton uptake was 4.69 picomole $/ 10^{6}$ cells per $\min (\mathrm{SD} 0.03, N=12)$ and 1.27 picomole (SD $0.75, N=10$ ) in the presence of amiloride (the residual influx is probably caused by incomplete inhibition of the exchanger). This result suggests that the exchanger is present, but apparently inactive under physiological conditions.

\section{Chloride distribution}

In the range of $\mathrm{pH}_{e} 7.0-8.0$ the chloride concentration decreases from $95.9 \mathrm{mmol} / \mathrm{kg}$ cell water to $73.8 \mathrm{mmol} / \mathrm{kg}$ cell water (mean values from 5 experiments). With total extracellular chloride of $148 \mathrm{mmol} / \mathrm{kg}$ water the ratio $\mathrm{Cl}_{i} / \mathrm{Cl}_{\mathrm{e}}$ falls from 0.65 to 0.5 . These values are much higher than those for the proton distribution ratio, which are 0.24 at $\mathrm{pH} 8.0$ and 0.36 at $\mathrm{pH}$ 7.0. Since the calculated proton equilibrium potential of $-38 \mathrm{mV}$ is close to the previously measured membrane potential of $-44 \mathrm{mV}$ at day 4 (Engelke et al., 1988), the intracellular chloride concentration is kept above the electrochemical equilibrium.

\section{Cell pH measurements in the presence of $\mathrm{CO}_{2}$}

Figures 2 and 4 also contain the results of the cell $\mathrm{pH}$ measurements carried out in the presence of $1 \%$ $\mathrm{CO}_{2}$ compared with data obtained at the same external $\mathrm{pH}$ but in the absence of $\mathrm{CO}_{2}$. Although all experiments were carried out in the absence of the Band 3 inhibitor DIDS the cell $\mathrm{pH}$ values are the same in the absence and presence of $\mathrm{CO}_{2}$. This result supports our previous suggestion that Band 3 protein in primitive red cells is not involved in substantial bicarbonate-chloride heteroexchange (Engelke $e t$ al., 1988) sufficient to establish equal distribution ratios for both ions.

\section{DISCUSSION}

The immature primitive red cells from the chick embryo that we investigated in the present paper are still dividing at day 4 and will undergo an estimated two additional divisions before final maturation (Campbell et al., 1971).

The neccessity to carry out oxygen transport without compromising the last proliferative cycles may require a $\mathrm{pH}$ regulation different from that of mature red cells, where the presence of Band 3 protein causes equal distribution ratios for protons, chloride and bicarbonate, so that cell $\mathrm{pH}$ can be calculated from the chloride distribution ratio (Van Slyke et al., 1923; Funder and Wieth, 1966; Hladky and Rink, 1977). Indeed the results of the present study show a pattern of $\mathrm{pH}$ control in the early embryonic red cell that differs substantially from that of the adult red cell.

\section{Steady state $\mathrm{pH}$ in embryonic red cells}

Measurements of cell pH in non-transformed proliferating erythroid cells have not been carried out before. We found a good agreement between the two methods used in our study to assess cell $\mathrm{pH}$, in particular the fluorescent label SNARF/1 seems well

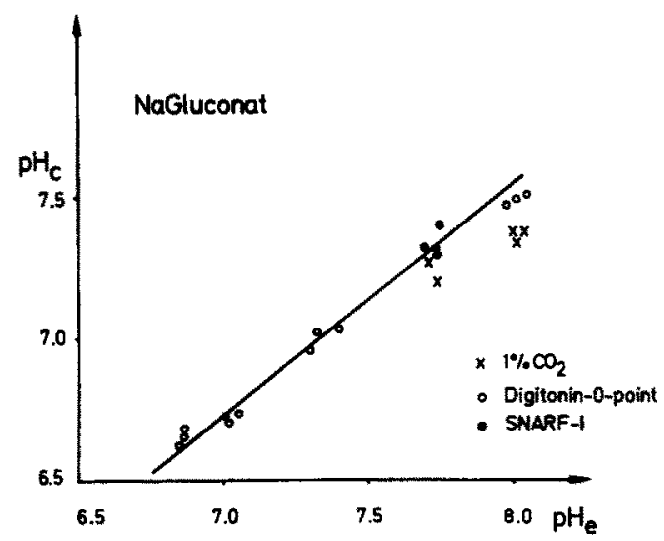

Fig. 4. Effect of substitution of external chloride by gluconate on cell pH. Measurements in the presence of carbon dioxide were obtained with SNARF-1. 
suited to monitor cell $\mathrm{pH}$ in the range above $\mathrm{pH} 7.0$. Nevertheless leakage still prevents continuous registration of cell $\mathrm{pH}$ and we are currently trying to reduce it with aid of organic anion transport inhibitors.

The $\mathrm{pH}$ difference of $0.61 \mathrm{pH}$ units between red cell and extracellular medium at $\mathrm{pH}_{\mathrm{e}} 8.0$ is of the same size as at day 6 (Baumann et al., 1982). The principal mechanism controlling cell $\mathrm{pH}$ of embryonic red cells during early development seems to be the proton conductance present in the membrane, whose molecular mechanism is not established (Engelke et al , 1988).

The steady state pH is unchanged when the Band 3 protein is blocked with DIDS. Furthermore red cell $\mathrm{pH}$ is unaltered when measured in the presence of carbon dioxide and hardly affected by substitution of gluconate for chloride. Replacement of sodium by choline has no measurable influence on steady state $\mathrm{pH}$ in the range $\mathrm{pH}_{\mathrm{e}} 7.4$ to about 8.3 (corresponding to an intracellular pH of around 6.9 to 7.55 ).

While the experiments carried out at $\mathrm{pH}_{\mathrm{e}} 6.6$ in the absence of external sodium demonstrate the presence of a sodium dependent proton fiux one must conclude that even at acid $\mathrm{pH}_{\mathrm{c}}$ the physiological importance of the exchanger is reduced. Under normal conditions the driving force for sodium-proton exchange is less than in adult red cells, due to the high intracellular sodium concentrations which under our experimental condition e.g. with an external sodium of $140 \mathrm{mmol} / \mathrm{l}$ amounts to about $80 \mathrm{mmol} / \mathrm{kg}$ cell water. Further experiments have to clarify the mechanisms that cause the high intracellular sodium concentration and keep the intracellular chloride concentration well above electrochemical equilibrium, a possible candidate is the $\mathrm{Na}-\mathrm{K}-\mathrm{Cl}$ cotransport system.

\section{Role of Band 3 protein in embryonic red cells}

The presence of Band 3 protein in the membrane of primitive red cells is well documented. Chan (1977) as well as Cox et al. (1987) found Band 3 protein as early as day 3 .

Our results demonstrate that there is no substantial heteroexchange of bicarbonate for chloride in early embryonic red cells. The presence of significant heteroexchange should result in an increase of red cell $\mathrm{pH}$ in the presence of bicarbonate since the Band 3 protein tends to equilibrate the bicarbonate and chloride distribution and $r_{\mathrm{Cl}}$ is much higher than $r_{\mathrm{H}}$.

However our cell $\mathrm{pH}$ data are the same in the absence or presence of $\mathrm{CO}_{2}$, this implies that chloride and bicarbonate are not in equilibrium with each other. It follows that the hetero-exchange function of the Band 3 protein is altered in embryonic red cells. We do not know the cause for the altered functional behaviour. The presence of covalent modifications affecting the cytoplasmic domain is one possibility since a tyrosine kinase which in vitro phosphorylates Band 3 has been demonstrated (Hillsgrove et al., 1987) in avian erythrocytes. Further experiments have given evidence that two Band 3 protein sequences exist in avian red cells, which apparently differ at the cytoplasmic domain (Kim et al., 1988). There is as yet no information available as to whether the two proteins differ in their functional properties and if their insertion into the plasma membrane is developmentally regulated.

In the adult chick red cell Band 3 protein has the same functional characteristics as Band 3 of human red cells (Jay, 1983). The divergent results obtained for cmbryonic red cells demonstrate that the regulation of cell $\mathrm{pH}$ and of Band 3 protein function during development is more complicated than allowed for by the present models describing these functions in adult red cells. Further experiments are necessary to extend the model and identify the developmentally regulated control mechanisms.

Acknowledgement-This research was supported by DFG Ba 691/4-1.

\section{REFERENCES}

Baumann R. and Haller E. A. (1983) Chloride distribution and intracellular $\mathrm{pH}$ of primitive red cells from chicken blood. Naunyn -Schniedegbergs Arch. Pharm. (Suppl) 322, R23.

Baumann R., Padeken S. and Haller E. A. (1982) Functional properties of embryonic hemoglobins $H$. appl. Physiol. 53, 1439-1448.

Brahm J. (1986) The physiology of anion transport in red cells. In Progress in Haematology, Vol. XIV, pp. 1-121.

Campbell G., Weintraub H., Mayall B. H. and Holtzer H. (1971) Primitive erythropoiesis in early chick embryogenesis II. Correlation between hemoglobin synthesis and the mitotic history. J. Cell. Biol. 50, 669-681.

Chan L. N. (1977) Changes in the composition of plasma membrane proteins during differentiation of embryonic chick erythroid cell Proc. nam. Acad. Sci. 74, 1062-1066.

Cox J. V., Stack J. H. and Lazarides E. (1987) Erythroid anion transporter assembly by a developmetally regulated recruitement onto a preassembled membrane cytoskeleton. J. Cell. Biol. 105, 1405-1416.

Engelke M., Zingel W. and Baumann R. (1988) Membrane potential of primitive red cells from chick embryo is a proton potential. J. Cell. Physiol. 135, 87-93.

Funder J. and Wieth J. O. (1966) Chloride and hydrogen ion distribution between human red cells and plasma. Acta physiol. Scand. 68, 234-245.

Hillsgrove D., Shores C. G., Parker J. C. and Maness P. F. (1987) Band 3 tyrosine kinase in avian erythrocyte plasma membrane is immunologically related to pp60 $00^{-s r c}, A m . J$. Physiol. 253, 286-295.

Hladky S. B. and Rink T. (1977) pH equilibrium across the red cell membrane. In Membrane Transport in Red Cells (Edited by Ellory J. C. and Lew V. L.), pp. 115-136. Academic Press, New York.

Jay D. G. (1983) Characterization of the chicken erythrocyte anion exchange protein. $J$. biol. Chem. 258, 9431-9436.

Kim H. Ch., Yew N. S., Ansorge E., Voss H., Schwager Ch., Vennström B., Zenke M. and Engel J. D. (1988) Two different mRNAs arte transcribed from a single genomic locus encoding the chicken erythrocyte anion transport Protein (Band 3) Mol. Cell. Biol. 8, 4416-4424.

Meuer H. J., Sieger U, and Baumann R. (1989) Measurement of $\mathrm{pH}$ in blood vessels and interstitium of 4 and 6-day-old chicken embryos. J. Dev. Physiol. 11, 354-359. 
Rink T. J., Tsien R. Y. and Pozzan T. (1982) Cytoplasmic $\mathrm{pH}$ and free $\mathrm{Mg}^{2+}$ in lymphocytes. J. Cell. Biol. 95, 189-196.

Thomas J. A. (1986) Intracellularly trapped pH indicators. In Optical Methods in Cell Physiology (Edited by DeWeer
P. and Salzberg B. M.), pp. 311-326. Wiley-Interscience, New York.

Van Slyke D. D., Wu H. and McLean F. C. (1923) Studies of gas and electrolyte equilibria in the blood. $J$. biol. Chem. 56, 765-849. 